\title{
DESCRIPTION OF A NEW SPECIES OF THE GENUS TETRALEURODES COCKERELL (HEMIPTERA: ALEYRODIDAE) WITH A KEY TO INDIAN SPECIES
}

\author{
A.K. Dubey ${ }^{1}$ and R. Sundararaj ${ }^{2}$ \\ ${ }^{1}$ Insect Museum, Centre for Ecological Sciences, Indian Institute of Science, Bangalore, Karnataka 560012, India \\ ${ }^{2}$ Wood Biodegradation Division, Institute of Wood Science \& Technology, $18^{\text {th }}$ Cross Malleswaram, Bangalore, Karnataka 560003 , India \\ Email: ${ }^{1}$ akdubey@ces.iisc.ernet.in; ${ }^{2}$ rsundar@iwst.res.in (corresponding author)
}

\begin{abstract}
The whitefly genus Tetraleurodes Cockerell from India was studied. A new species Tetraleurodes dendrocalamae breeding on Dendrocalamus strictus in Kudremukh National Park, Karnataka, India, is described and illustrated. A key to the Indian species of the genus is given.
\end{abstract}

\section{KEYWORDS}

Whitefly, Aleyrodidae, Hemiptera, Tetraleurodes dendrocalamae sp. nov., Dendrocalamus strictus

The whitefly genus Tetraleurodes Cockerell is represented by 70 described species almost worldwide (Martin, 1999). In India this genus is so far represented by five species. A new species of this genus from Western Ghats, Karnataka, southern India is described with a key to the Indian species in this paper.

\section{Tetraleurodes bambusae Jesudasan \& David} Jesudasan \& David, 1991. Oriental Ins. 25: 332

\section{Material examined}

Holotype: 4.viii.1984, Siruvani forest (Coimbatore), Tamil Nadu, India, puparium on Bambusa sp., coll. R.W.A. Jesudasan. Host: Bambusa sp. (Jesudasan \& David, 1991).

Distribution: India: Tamil Nadu (Jesudasan \& David, 1991).

2. Tetraleurodes burliarensis Jesudasan \& David Jesudasan \& David, 1991. Oriental Ins. 25: 332-333.

\section{Material examined}

Holotype: 20.vi.1985, Burliar, Tamil Nadu, India, puparium on unidentified tree, coll. R.W.A. Jesudasan.

Host: Unidentified tree (Jesudasan \& David, 1991).

Distribution: India: Tamil Nadu (Jesudasan \& David, 1991).

\section{Tetraleurodes dendrocalamae sp. nov.}

(Figs. 1-3)

\section{Material examined}

Holotype: 10.viii.2001, Kudremukh National Park, Karnataka, India, puparium on slide, on Dendrocalamus strictus, coll. A.K. Dubey, Forest Research Institute, Dehradun, India (Registration number not yet received).

Paratypes: 10 puparia mounted on slides, data as for holotype. One paratype each deposited in Australian National Insect Collection, CSIRO Entomology, Canberra, ACT, Australia; The Natural History Museum, London, United Kingdom; Division of Entomology, Indian Agricultural Research Institute, New Delhi, India; National Museum of Natural History, Tel Aviv University, Israel; Staatliches Museum fur Tierkunde, Dresden, Germany; Systematic Entomology Laboratory, U.S. Department of Agriculture, Beltsville, Maryland, USA; Zoological Museum, Universitetsparken, Department of Zoology, Copenhagen, Denmark and Zoological Survey of India, Calcutta, India. (Registration numbers not yet received).

\section{Host: Dendrocalamus strictus.}

\section{Etymology}

Named after the host genus Dendrocalamus.

\section{Diagnostic features}

Puparium: Black, without secretion of wax; octahedral in shape, broadest at transverse moulting suture region; $0.67-0.76 \mathrm{~mm}$ long, $0.38-0.44 \mathrm{~mm}$ wide; found singly, 2-3 per leaf on lower surface. Margin toothed, teeth rugose and arranged in two rows, $16-18$ teeth in $0.1 \mathrm{~mm}$. Thoracic and caudal tracheal pores not differentiated from margin. Anterior and posterior marginal setae respectively, $14 \mu \mathrm{m}$ and $16 \mu \mathrm{m}$ long.

Dorsum: Tuberculated. Submargin separated from dorsal disc by a prominent furrow, reaching caudal end posterior to vasiform orifice. Submargin near submarginal furrow without any tubercles or pores. A pair of lateral longitudinal rugose ridge on subdorsum extending from prothorax to second abdominal segment. A pair of faint lateral longitudinal ridges present on abdominal submedian area, connecting submedian depressions. Submedian pockets present on all abdominal segment sutures. Submedian depressions present on mesoand metathoracic segment sutures. Longitudinal moulting suture reaching margin and transverse moulting suture reaching near submarginal furrow. Dense microtubercles on submargin form distinct papillae-like submarginal ridges, not reaching submarginal furrow. Subdorsal and submedian areas ornamented by minute tubercles, running along the abdominal segment sutures. Median length of abdominal segment VII subequal to VIII. A series of minute pores and porettes present on submargin and several pores and porettes scattered throughout dorsum.

Chaetotaxy: Dorsal setae five pairs- cephalic setae $31 \mu \mathrm{m}$ long, mesothoracic setae $60 \mu \mathrm{m}$ long, metathoracic setae $50 \mu \mathrm{m}$ long, eighth abdominal setae cephalolaterad of vasiform orifice $62 \mu \mathrm{m}$ long and caudal setae arising from submarginal microtubercles 


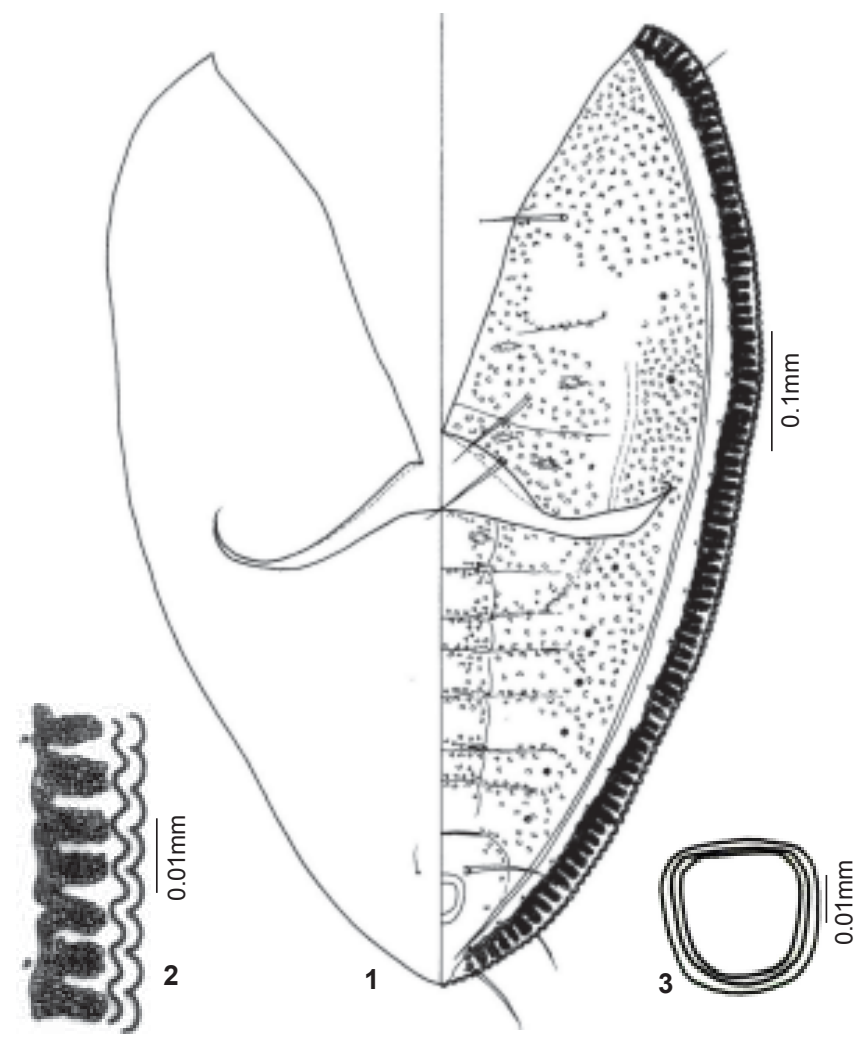

Figures 1-3. Tetraleurodes dendrocalamae sp. nov. 1 - Puparium; 2 - Margin; 3 - Vasiform orifice

$69 \mu \mathrm{m}$ long. First abdominal setae absent. Eight pairs of minute setae on subdorsum, their bases distinct.
Vasiform orifice: Elevated, subrectangular, 31-41 $\mu \mathrm{m}$ long, 34$40 \mu \mathrm{m}$ wide; operculum subrectangular, 24-34 $\mu \mathrm{m}$ long, 24-36 $\mu \mathrm{m}$ wide, lingula concealed. Thoracic and caudal tracheal furrows absent.

Venter: Paired ventral abdominal setae $10 \mu \mathrm{m}$ long, $21 \mu \mathrm{m}$ apart.

\section{Remarks}

This species resembles Tetraleurodes pusana Takahashi in shape, presence of metathoracic setae and subractangular vasiform orifice, but differs in the presence of mesothoracic setae, lateral longitudinal rhachis on subdorsum, tuberculated dorsum and distinct submarginal ridges. It is also closer to Tetraleurodes neemani Bink-Moenen in shape and in the presence of mesothoracic and metathoracic setae but differs from it in submarginal structures, presence of eight pairs of minute subdorsal setae and structural detail of vasiform orifice.

\section{Tetraleurodes kunnathoorensis Regu \& David}

Regu and David, 1993. Hexapoda 5(1): 53-56.

\section{Material examined}

Holotype: 21.i.1991, Kunnathoor, Tamil Nadu, puparium on Streblus asper, coll. K. Regu.

Host: Streblus asper (Regu \& David, 1993).

Distribution: Kunnathoor (Regu \& David, 1993).

\section{Tetraleurodes pusana Takahashi}

Takahashi, 1950. Annot. Zool. Japan, 23:86.

\section{Material examined}

Holotype: 5.xii.1971, Madras, Tamil Nadu, one puparium on

Key to the Indian species of Tetraleurodes

1. Puparium black or bluish-black

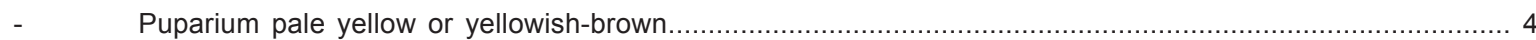

2. Dorsal setae/ meso-, metathoracic setae/ submarginal/ subdorsal setae present 3 Dorsal setae/ meso-, metathoracic setae/ submarginal/ subdorsal setae absent

3. Margin with 8-10 teeth in $0.1 \mathrm{~mm}$; submedian setae on meso- and metathorax absent; submargin without a row of microtubercles; vasiform orifice cordate...... kunnathoorensis Regu \& David

Margin with 16-18 teeth in $0.1 \mathrm{~mm}$; submedian setae on meso- and metathorax present; submargin with a row of microtubercles; vasiform orifice subrectangular... dendrocalamae sp. nov.

4. Puparium pale yellow with wax around margin; cephalic and metathoracic setae short; dorsum with granules and sculptures

Puparium yellowish-brown with no wax; cephalic and metathoracic setae very long; dorsum without granules and sculptures pusana Takahashi

5. Dark brown patch on dorsum absent; marginal setae wanting; cephalic setae $17.5 \mu \mathrm{m}$ long, metathoracic setae $12.5-15.0 \mu \mathrm{m}$ long and eighth abdominal setae $17.5 \mu \mathrm{m}$ long; vasiform orifice wider than long .....

thenmozhiae Jesudasan \& David

A distinct dark brown patch on dorsum present; marginal setae present; cephalic setae $38 \mu \mathrm{m}$ long, metathoracic setae $43.7 \mu \mathrm{m}$ long and eighth abdominal setae $27.5-40.0 \mu \mathrm{m}$ long; vasiform orifice as long as wide....

bambusae Jesudasan \& David 
grass, coll. B.V. David.

Host: Unidentified Grass (Takahashi, 1950).

Distribution: India: Bihar (Pusa) (Takahashi, 1950); Tamil Nadu.

6. Tetraleurodes thenmozhiae Jesudasan \& David Jesudasan \& David, 1991. Oriental Ins. 25: 333-334.

\section{Material examined}

Holotype: 20.vi.1985, Burliar, Tamil Nadu, puparium on Cinnamomum sp., coll. R.W. Alexander Jesudasan. Host: Cinnamomum sp. (Jesudasan \& David, 1991).

Distribution: India: Tamil Nadu (Jesudasan \& David, 1991).

\section{REFERENCES}

Jesudasan, R.W.A. and B.V. David (1991). Taxonomic studies on Indian Aleyrodidae (Insecta: Homoptera). Oriental Ins. 25: 231-434.

Martin, J.H. (1999). The whitefly fauna of Australia (Sternorrhyncha: Aleyrodidae). A taxonomic account and identification guide. CSIRO Entomology Technical Paper 38: 1-197.

Regu, K. and B.V. David (1993). Two new species of whiteflies (Aleyrodidae: Homoptera) from India. Hexapoda 5: 53-56.

Takahashi, R. (1950). Four new species of Aleyrodidae (Homoptera) from Australia, India and Borneo. Annotnes Zoology of Japan 23: 8588

\section{ACKNOWLedGements}

The authors are grateful to Dr. K.S. Rao, Director, Institute of Wood Science and Technology, Bangalore for the facilities provided. Thanks are due to Prof. B.V. David, President, Sun Agro Biotech Research Centre, Porur, Chennai for confirming the identity of the species and Prof. C.A Viraktamath, Department of Entomology, University of Agricultural Sciences, GKVK, Bangalore for his valuable comments. Financial assistance provided by the Ministry of Environment and Forests, Govt. of India for conducting this research work, is also acknowledged with thankfulness.

\section{Volunteers needed}

The Chiroptera Conservation and Information Network of South Asia (CCINSA) along with Dr. Shahroukh Mistry, USA, have embarked on a project that involves identification and monitoring of fruit bat (Pteropus giganteus) colonies/ roosts all over South Asia. The project will be an ongoing one with regular monitoring of colonies to understand the dynamics, population trends and various other aspects of regions largest bats.

The project is not funded yet. However, if you or any one of your colleagues or friends are interested in joining this exciting project, please write with your name, address, occupation, interest in this subject, and the geographical area you would like to participate in monitoring fruit bats.

We already have a few volunteers who have started work in different parts of South Asia. South Asia is a large region and we need many more people.

Write to us at the earliest to be part of this long-term, first of its kind project:

Ptero Count

Sanjay Molur / Sally Walker

Zoo Outreach Organisation

29-1 Bharathi Colony

Peelamedu

Coimbatore 641004

Email: herpinvert@vsnl.com

Ph: +91 422 2568906, 2561743, 2561087

Fx: +914222563269 